\title{
COMPARISON OF PPT AND APTT IN PRE AND POST-HEMODIALYSIS PATIENTS AS THE HEPARIN-EXPOSED EFFECT
}

\author{
Yetti Hernaningsih ${ }^{1}$, Widodo $^{2}$, Koko Aprianto $^{3}$ \\ ${ }^{1}$ Department of Clinical Pathology, ${ }^{2}$ Department of Internal Disease, ${ }^{3}$ Resident in Training, Department of Clinical \\ Pathology, Faculty of Medicine, Universitas Airlangga, Dr. Soetomo Hospital, Surabaya, Indonesia
}

\section{ABSTRACT}

Evaluations on Plasma Prothrombin Time (PPT) and Activated Partial Thromboplastin Time (APTT) are required in patients with Chronic Kidney Disease (CKD) stage $V$ to determine the risk of bleeding after hemodialysis (HD) using heparin as the anticoagulant. This study aimed to compare the results of PPT and APTT in pre and post-hemodialysis patients with minimum dose of heparin. This was an observational-analytical study with cross-sectional design. The samples were collected in HD wards of Dr. Soetomo Hospital, Surabaya. There were 50 PPT and APTT samples collected from June to August 2017. The samples were evaluated using the tool CoaDATA 501. The examination of coagulation study was conducted in Clinical Pathology Laboratory of Dr. Soetomo Hospital, Surabaya. Paired t-test and Wilcoxon signed-rank test were performed in this study. In the 50 samples, prehemodialysis PPT ranged between 10.2-17.6 with the mean of 12.6 \pm 2.03 seconds, while for post-hemodialysis, the range was 10.120.9 with the mean of 13.41 +2.43 seconds. Pre-hemodialysis APPT ranged between 19.5-75.2 with the mean of 30.32 \pm 10.43 seconds, while in post hemodialysis the range was 22.21-175 with the mean of 37.52 \pm 26.40 seconds. The results of PTT evaluation in pre and post-HD showed no significant difference $(p=0.083)$, while those of APTT showed a significant difference $(p=0.035$ or $p<0.05)$. Prolongation of APTT in post-HD is due to the use of heparin as an anticoagulant that increases PPT and APTT by inhibiting antithrombin III. HD procedures cause decreased activity of coagulation factors II, IX, X, XII leading to APTT prolongation in post$H D$. A significant APTT prolongation was found in post-HD patients with CKD $\mathrm{V}$.

Keywords: PPT; APTT; CKD V; heparin; CoaDATA 501

\begin{abstract}
ABSTRAK
Evaluasi Waktu Prothrombin Plasma (PPT) dan Waktu Tromboplastin Partial Aktif(APTT) diperlukan pada pasien dengan Penyakit Ginjal Kronik (CKD) tahap V untuk menentukan risiko perdarahan setelah hemodialisis (HD) menggunakan heparin sebagai antikoagulan. Penelitian ini bertujuan untuk membandingkan hasil PPT dan APTT pada pasien pra dan pasca hemodialisis dengan dosis minimum heparin. Ini adalah penelitian analitik observasional dengan desain cross-sectional. Sampel dikumpulkan di ruang HD Rumah Sakit Umum Dr. Soetomo Surabaya. Ada 50 sampel PPT dan APTT yang dikumpulkan dari Juni hingga Agustus 2017. Sampel dievaluasi menggunakan alat CoaDATA 501. Pemeriksaan studi koagulasi dilakukan di ruang patologi klinis Rumah Sakit Umum Dr. Soetomo Surabaya. Paired t-test dan Wilcoxon signed-rank test dilakukan dalam penelitian ini. Dalam 50 sampel, prahemodialisis PPT berkisar antara 10,2-17,6 dengan rata-rata 12,6 \pm 2,03 detik, sedangkan untuk pasca-hemodialisis, kisarannya adalah 10,1-20,9 dengan rata-rata 13,41 $\pm 2,43$ detik. Pra-hemodialisis APPT berkisar antara 19,5-75,2 dengan rata-rata 30,32 \pm 10,43 detik, sedangkan dalam post hemodialisis kisarannya adalah 22,21-175 dengan rata-rata 37,52 $\pm 26,40$ detik. Hasil evaluasi PTT pada pra dan pasca-HD menunjukkan tidak ada perbedaan yang signifikan $(p=0,083)$, sedangkan mereka dari APTT menunjukkan perbedaan yang signifikan $(p=0,035$ atau $p<0,05)$. Perpanjangan APTT pada pasca-HD disebabkan oleh penggunaan heparin sebagai antikoagulan yang meningkatkan PPT dan APTT dengan menghambat antitrombin III. Prosedur HD menyebabkan penurunan aktivitas faktor koagulasi II, IX, X, XII yang menyebabkan perpanjangan APTT pada pasca-HD. Perpanjangan APTT yang signifikan ditemukan pada pasien pasca-HD dengan CKD $V$.
\end{abstract}

Kata kunci: PPT; APTT; CKD V; heparin; CoaDATA 501

Correspondence: Yetti Hernaningsih, Department of Clinical Pathology, Faculty of Medicine, Universitas Airlangga, Surabaya, Indonesia. E-mail:

pISSN:2355-8393 • eISSN: 2599-056x • doi: http://dx.doi.org/10.20473/fmi.v55i3.15491

- Fol Med Indones. 2019;55:166-170 • Received 18 Jan $2018 \bullet$ Accepted 9 Aug 2018

- Open access under CC-BY-NC-SA license • Available at https://e-journal.unair.ac.id/FMI/ 


\section{INTRODUCTION}

Chronic Kidney Disease (CKD) is damage occurs in kidney for more than three months, based on pathological abnormalities or kidney failure signs such as proteinuria. If no kidney damage is found, the diagnosis of CKD is then established using gromerular filtration rates (GFR) of $<60 \mathrm{ml} /$ minute $/ 1.73 \mathrm{~m} 2$. The limitation of CKD comprises kidney damage of more than three months including renal structural or functional abnormalities, with or without decreased GFR based on pathological abnormalities and kidney damage signs such as proteinuria or abnormalities in imaging examination (radiology) with GFR of $<60$ $\mathrm{ml} / \mathrm{minute} / 1.73 \mathrm{~m} 2$ (Sudoyo 2009, Chonchol 2005). Until present, the data collected by Indonesian Renal Registry (IRR) during 2007-2008 show that the most ranked etiologies causing CKD are glomerulonefitris $(25 \%)$, diabetes mellitus or DM $(23 \%)$ and polycystic kidney $(10 \%)$. The prevalence of CKD stage $\mathrm{V}$ is a worldwide problem that keeps developing and affects the increased rate of life-threatening complications (Widodo 2009). The current therapy for CKD V (with GFR of $<15 \mathrm{ml} /$ minute) is renal replacement therapy, including renal transplantation and dialysis (hemodialysis and peritoneal dialysis) (Sherwood 2001). Renal transplantation is still the golden standard of CKD V therapies, but the most frequently used one is dialysis, both hemodialysis and peritoneal dialysis, due to its practicality and low cost as in renal transplantation (Suwitra 2006, Chonchol 2005).

Hemodialysis is a renal replacement therapy for longterm control in End-Stage Renal Disease (ESRD) patients. Hemodialysis is a blood separation or filtering or cleaning process through a semi-permeable membrane conducted in patients with renal function impairment both chronic and acute (Price SA, 2006). Hemodialysis in CKD V takes part in getting rid of toxic materials, such as urea, from the plasma as well as correcting the electrolyte abnormalities in the body (Suwitra 2006). In hemodialysis, anticoagulant is necessary to prevent blood clots within the extracorporeal circuit (Widodo 2009). Several anticoagulant techniques that were made according to the patients' conditions have been tested. Several anticoagulants other than heparin have also been tested and some others are still attempted. The purpose of all these efforts is to obtain anticoagulant with no side effect in long-term use. However, based on its simple administration, high-molecular-weight heparins (Unfractioned Heparin) is still considered the standard anticoagulant used in hemodialysis process (Kim 2003). Hemodialysis will repair abnormal hemostasis in uremia, but heparinization during hemodialysis procedures increases the risk of bleeding (Dara 2009,
Mohammed 2008). The bleeding risk can be minimized by preventing blood clots in extracorporeal circulation during hemodialysis through the administration of minimum heparinization and heparin-free dialyis as well as the use of low-molecular-weight heparin (LMWH) anticoagulation (Lohr 2008).

The global prevalence of pre-dialysis patients, particularly hemodialysis, increases very rapidly in all around the world and is often conducted in CKD patients (Abdalla 2014). However, the unexpected effects of dialysis therapy in various blood components are inevitable (Pandian 2001, Mohammed 2008). The risk of bleeding or thrombosis is associated with thrombocyte function defects in patients with CKD V where the use of anticoagulant in hemodialysis procedure might compound the risk (Kim 2003). Coagulation study measurement, particularly the coagulation parameter plasma prothrombin time (PPT) and activated partial thromoplastin time (APTT), is the screening test for coagulation abnormality or impairment in extrinsic, intrinsic and joint coagulation pathway (Prasanto 2007). Plasma prothrombin time (PPT) detects the abnormality of extrinsic pathway by measuring the time of clot formation if thromboplastin reagents and $\mathrm{Ca} 2+$ are added to the plasma $\left(37^{\circ} \mathrm{C}\right)$. The results are reported in seconds and the ratio of the patients' PPT/PPT control. In monitoring the use of anticoagulant, PPT rates are uniformed using INR (International Normalize Ratio)15. Increased PPT is found in the deficiency of factors V, VII, X, II, I (Sherwood, 2001). It is to measure the clot formation time if activator and $\mathrm{Ca} 2+$ ion are added into the plasma $\left(37^{\circ} \mathrm{C}\right.$ ). Activator acts as the contract factor (subendothelial tissue). The frequently used activators are kaolin, elagic acid, celite and micronized silica (Angus 1995).

Hemostatis physiology examination, particularly PPT and APTT, consists of manual and automatic examination, in which the manual one (Tilt tube and Hook) is said to be the reference for PPT and APTT examination (Angus 1995). Whereas, there are currently two automatic examination methods in general that are commonly used and developing. The principle of the optical photo method (optical flowcytometri) is to detect changes in blood turbidity during coagulation process as the changes of light intensity received by photodiode that turns the light intensity into electrical signals. The signals are stored and calculated to determine the coagulation time (Angus 1995). The coagulometer tool COADATA 501 applies the principle of optical photo method. Another automatic method is electromechanical impedance method which principle is that in the cuvette of the examination there is a stainless ball that moves due to electromagnetic fields around it. When the 
plasma clots, the ball stops. The time from when the ball moves until it stops is recorded as the clotting time. This electromagnetic method is considered unaffected by the conditions of samples with HIL (hemolysis, icterus/jaundice and lipemic), but the result reading could be affected by the increased blood viscosity in high sample of fibrinogen, as in patients using hormonal contraception and having acute infection, collagen diseases, diabetes, inflammation as well as obesity. Besides, it could also be affected by the plasma proteins, such as paraprotein, globulin (which binds the insoluble hormones such as thyroid, steroid, ferum, bilirubin, cholesterol) (Angus 1995).

In deficiency of coagulation factor I, II, V, VIII, IX, X, $\mathrm{XI}$ and XII, there was increased APTT. The parameters also serve as the basis for patient management by monitoring the bleeding risk, adjusting the dose of coagulants such as heparin, evaluating the treatment quality and predicting the risk of complications in patients with CKD V (Khalid \& Zafar 2015). Examinations of PPT and APTT are simple and easy to conduct and therefore these parameters are accepted as the best signs to determine the physiology of coagulation in pre and post-dialysis patients with CKD V (Sudoyo 2009).

The previous researchers have explained a different result of blood component between pre and posthemodialysis, but in general, no study on the effect of hemodialysis on various components has been conducted in Indonesia, particularly in dr. Soetomo General Hospital. Thus, this study is conducted to observe the comparison of PPT and APTT results in pre and post-hemodialysis patients affected by the use of the anticoagulant heparin.

\section{MATERIALS AND METHODS}

This is an analytical-observational study with crosssectional design. The samples were collected in HD room of Dr. Soetomo General Hospital Surabaya from June to August 2017. Coagulation study examination was conducted in clinical pathology room of Dr. Soetomo General Hospital Surabaya. The samples of PPT and APTT were 50 blood plasma with anticoagulant citrate randomly collected from patients with CKD V. Data were collected from medical records as well as anamnesis. The inclusion criterion was patients with CKD V undergoing hemodialysis twice in at least two months with minimum dose of heparin. The exclusion criterion was patients with DIC (disseminated intravascular coagulation), malignancy, congenital and secondary hypercoagulability and advanced liver diseases. The data were analyzed using SPSS 17.0.
Paired t-test and Wilcoxon signed-rank test were performed. $\mathrm{P}$ value of $<0.05$ indicated no statistically significant difference.

\section{RESULTS}

The subjects were $28(56 \%)$ males and $22(44 \%)$ females. Hypertension was found in 29 (58\%) samples, while the other $21(42 \%)$ had DM. All patients were treated with hemodialysis regularly, twice a week for 4 hours since at least three months.

In pre-hemodialysis, PPT ranged between 10.2-17.6 seconds with mean of $12.6 \pm 2.03$ seconds, while APTT ranged between 19.5-75.2 seconds with mean of $30.32 \pm 10.43$ seconds. In post-hemodialysis, PPT ranged between 10.1-20.9 seconds with mean of 13.41 \pm 2.43 seconds, while APTT ranged between 22.2-175 seconds with mean of $37.52 \pm 26.40$ seconds (Table 3). The normality test results of PPT and APTT in pre and postHD using Kolgomorov-Smirnov show that the data were not normally distributed. Data homogeneity test results of PPT and APTT in pre and post HD using Saphiro-Wilk show the data as homogeny.

\section{DISCUSSION}

Minimum heparin dose was used in this examination of PPT and APTT in pre and post-HD since nearly all patients used the minimum dose of heparin when this study was conducted. It is due to the single-use dialyzer which does not require standardized heparin dose. The obtained results show increased APTT in pre and postHD. It is possibly due to the use of heparin as the anticoagulant in the HD procedures. Heparine binds the enzyme antithrombin III which activates the factor IXa and causes APTT prolongation. Meanwhile, there was no significance difference in PPT. This study corresponds with a study by Abdalla Sana E. and Ahmed Emad, both for APTT and PPT. Their study reported a significant increase of APTT and D-dimet in post-HD, but no significant increase was found in PPT. This study also corresponds with those of Alghytan A. et al. and Mohammad M. S. et al. conducted in 2012 showing no tendency of prolonged PPT and APTT in post-hemodialysis. However, this study only found the significant prolongation in APTT, not in PPT.

The significant difference between the two parameters due to the use of heparin as the anticoagulant in HD procedures is highly affected by the different types and doses of the anticoagulant leading to the tendency of bleeding and changes in the coagulation parameter in post-HD. Variations in individual, decreased duration of 
HD session and decreased HD quantity also affect the results difference. Other factors causing increase in the coagulation parameter are increased tissue factor pathway inhibitor (TFPI) levels and decreased activities of several coagulation factors during HD, including factor II, IX, X and XII.

Table 1. Characteristics of patients in PPT and APTT examination

\begin{tabular}{|c|c|c|}
\hline Variables & Sub-variables & Number \\
\hline \multirow[t]{3}{*}{ Age (year) } & $21-40$ & $5(10 \%)$ \\
\hline & $41-60$ & $35(70 \%)$ \\
\hline & $>61$ & $10(20 \%)$ \\
\hline \multirow[t]{2}{*}{ Gender } & Male & $28(56 \%)$ \\
\hline & Female & $22(44 \%)$ \\
\hline \multirow[t]{2}{*}{ Basic Disease } & Hipertension & $29(58 \%)$ \\
\hline & Diabetes melitus & $21(42 \%)$ \\
\hline
\end{tabular}

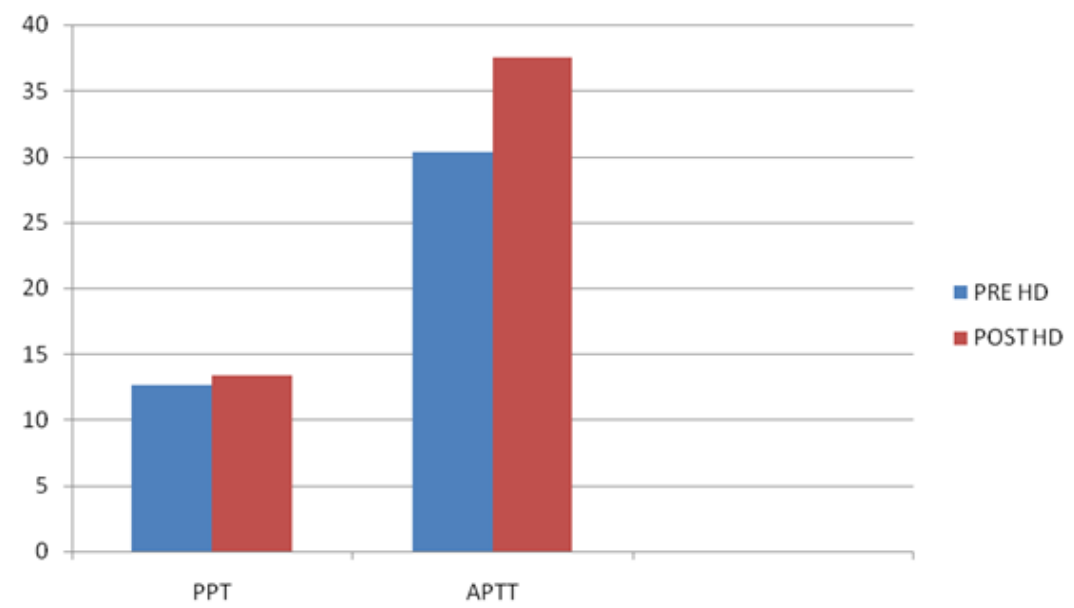

Fig. 1. PPT and APTT mean in pre dan post-HD.

Table 2. Normality test and homogeneity test of PPT and APTT in pre and post-HD

\begin{tabular}{lcccccc}
\hline & \multicolumn{3}{c}{ Kolmogorov-Smirnov $^{\mathrm{a}}$} & \multicolumn{3}{c}{ Shapiro-Wilk } \\
\cline { 2 - 7 } & Statistic & $\mathrm{df}$ & Sig. & Statistic & df & Sig. \\
\hline PRE HD PT & .151 & 50 & .006 & .909 & 50 & .001 \\
PRE HD APTT & .195 & 50 & .000 & .669 & 50 & .000 \\
POST HD PT & .121 & 50 & .064 & .889 & 50 & .000 \\
POST HD APTT & .322 & 50 & .000 & .478 & 50 & .000 \\
\hline
\end{tabular}

Table 3. Difference test result of PPT and APTT in pre and post-HD

\begin{tabular}{lcc}
\hline \multicolumn{1}{c}{ Variable } & Mean \pm SD & P value \\
\hline PPT & $12.6 \pm 2.03$ & 0.083 \\
Pre-HD & $13.41 \pm 2.43$ & \\
Post-HD & & \\
APTT & $30.32 \pm 10.43$ & 0.035 \\
Pre-HD & $37.52 \pm 26.40$ & \\
Post-HD & & \\
\hline
\end{tabular}




\section{CONCLUSION}

The coagulation parameters APTT in pre and post-HD patients with CKD V are different. This might be due to the use of heparin as antithrombin III and decreased activities of coagulation factor II, IX, X and XII during HD process. Monitoring of the coagulation parameters PPT and APTT helps in determining the risk of bleeding complications and the consequence of increased pain rates and therefore it can be used as patient management guidelines. Coagulation study measurement, particularly PPT and APTT, is the basis of management for patients with ESRD to maintain the risk of bleeding, adjust heparinization doses, evaluate treatment quality and predict the risk of complications.

\section{REFERENCES}

Abdalla SE, Ahmed EM (2014). The effect of haemodialysis on prothrombin time, active partial thromboplastin time, and $\mathrm{D}$ dimer in late stage renal failure patients. Sud Med Lab J 2, 27-35

Abdullah KA, Abbas HA (2012). Hematological changes before and after hemodialysis, Scientific Research and Essays Vol. 7(4), pp 490-497, 30 January, 2012

Angus RF (1995). Singapore Polytechnic, Chemical Process \& Biotechnology Department, Singapore 0513. 1st Ed. Singapore, p 19-40

Chonchol M, Spiegel DM (2005). Manual of Nephrology. 6th ed. Philadelphia, Lippincott Williams and Wilkins, p 177-186

Clarkson MR, Brenner BM (2009). Pocket companion to brenner \& rector's the kidney. 7th Ed. Philadelphia, Elsevier Saunders

Dara KM (2009). Effect of hemodyalisis and peritoneal dialysis on some hematological and biochemical parameters in renal failure. Zanjo J. Med 13
Khalid A, Zafar L (2015). Effect of haemodialysis on mean prothrombin time and activated partial thromboplastin time in patients of end stage renal disease. Journal of Rawalpindi Medical College (JRMC) 19, 247-249

Kim YG (2003). Anticoagulation during hemodyalisis patients at high-risk ofleeding Nephrology, 23-27

Lohr JW, Schwab SJ (2008). Minimizing hemorrhagic complication in dialysis patients. Journal of the American Society of Nephrology 2, 961-75

Mohammed SMA, Muna AB, Leena BM, Fadl AATA, Mekki HA (2008). Hematological changes post hemo and peritoneal dyalisis among renal failure in Sudan, Saudi J Kidney Dis Transpl 19, 274-279

Pandian J, Amitkumar K, Swaminathan A (2017). Assesment of impact hemodyalisis on hematological parameters among patients with chronic kidney disease.Comp Clin Pathol 26, 213-218

Prasanto H (2007). Hypercoagulation in chronic kidney disease. The 7th Jakarta Nephrology \& Hypertension Course. PERNEFRI, 25-27

Price SA, Wilson LM (2006). Patofisiologi. 6th Ed. Jakarta, EGC

Sherwood L (2001). Sistem kemih. Fisiologi manusia dari sel ke sistem. 2nd Ed. Jakarta, Penerbit Buku Kedokteran ECG, 463

Sudoyo AW (2009). Penyakit ginjal kronik. Buku Ajar Ilmu Penyakit Dalam. 5th Ed. Jakarta, Pusat Penerbitan IPD FK UI, p 1035-40

Sukandar E (2006). Neurologi klinik. 3rd Ed. Bandung, Pusat Informasi Ilmiah (PII) Bagian Ilmu Penyakit Dalam Fakultas Kedokteran UNPAD

Suwitra K (2006). Penyakit ginjal kronik. In: Sudoyo AW, Setiyohadi B, Alwi I, Marcellus SK, Setiati S, 4th Ed. Jakarta, Pusat Penerbitan Departemen Ilmu Penyakit Dalam FKUI, p 570-3 